\title{
OCCUPATIONAL ALLERGIC CONTACT DERMATITIS DISSEMINATED FROM MULTIFUNCTIONAL ACRYLATES IN ULTRAVIOLET-CURED LACQUERS
}

\author{
MARTA KIEĆ-ŚWIERCZYŃSKA, BEATA KRĘCISZ, and DOMINIKA ŚWIERCZYŃSKA-MACHURA \\ Department of Occupational Diseases \\ Nofer Institute of Occupational Medicine \\ Łodź, Poland
}

\begin{abstract}
A case of disseminated allergic contact dermatitis in a screen process printer is presented. The skin lesions were caused by multifunctional acrylates (methylpropane triacrylate and pentaerythritol triacrylate - highly positive patch tests $(+++)$ after 48 and $96 \mathrm{~h}$ ) present in ultraviolet cured transparent lacquer used in coat printed posters to make them weather-resistant. Patch tests with lacquer were also highly positive $(+++)$ after 48 and $96 \mathrm{~h}$. According to the safety sheet of the product, lacquer contained $85-90 \%$ of multifunctional acrylates. The patient showed disseminated dermatitis, however, no hypertrophied lesions on the hand skin, a characteristic symptom in persons exposed to acrylates, were observed.
\end{abstract}

Key words:

Acrylates, Trimethylolpropane triacrylate, Pentaerythritol triacrylate, Allergic contact dermatitis, Ultraviolet-cured lacquers, Occupation

\section{CASE REPORT}

A 54-year-old man, without history of atopy, has been working since 1979, first as a bookbinder, then as a screen-printing operator in his self-owned small business. Skin changes appeared 2 years ago. They were disseminated in character, located in the upper and lower extremities, face, neck and upper chest and included erythema with vesicles and papules. The patient experienced severe pruritus. The dermal changes occurred after contact with clear lacquers used by the patient to coat advertising posters in order to make them weather-resistant. The lacquers (UV6000 and UV9000) were obtained from Bousfield Printing Products Ltd, Bristol, UK. The lacquer was set by UV at 320-460 $\mu \mathrm{m}$. As per material safety data sheet, the lacquer contained: $85-90 \%$ multifunctional acrylates and 10-15\% photoinitiators and surfactants. Table 1 shows the results of patch tests.
Table 1. Patch test results

D2 D4

European Standard (Chemotechnique Diagnostics,

Malmö, Sweden)

4-Fenylenodiamine (1\% pet.)

$+\quad++$

(Meth) Acrylate Series-Printing (Chemotechnique

Diagnostics, Malmö, Sweden)

Trimethylolpropane triacrylate $(0.1 \%$ pet. $) \quad++\quad++$

Pentaerythritol triacrylated $(0.1 \%$ pet. $) \quad++\quad+++$

Lacquer UV6000 and UV9000

$20 \%$ aq.

$+++++$

$10 \%$ aq.

$+++++$

\section{DISCUSSION}

Multifunctional acrylates have been introduced into ultraviolet-cured painting inks since the 1970s. Some authors [4-6] reported allergic contact dermatitis from trimethy-

Received: February 14, 2006. Accepted: March 1, 2006.

Address reprint requests to Prof. M. Kieć-Świerczyńska, MD, PhD, Department of Occupational Diseases, Nofer Institute of Occupational Medicine, św. Teresy 8 , 91-348 Łódź, Poland (e-mail: marswier@imp.lodz.pl). 
lolpropane triacrylate (TMPTA), pentaerythritol triacrylate (PETA), and tripropylene glycol diacrylate (TPGDA) in inks. Goon et al. [7] reported a case of allergy to those chemicals in a worker of a company manufacturing acrylate polymers for making superabsorbent polymers used in diapers. Reports of varnish allergy are rare. Estlander et al. [8] reported occupational contact dermatitis from UVcured lacquer for painting wood, containing dipropylene glycol diacrylate (DPGDA).

Our patient had dermatitis disseminata; eczema hyperkeratoticum manuum, very frequent in other patients exposed to acrylates, was not observed [3].

\section{REFERENCES}

1. Nakamura M. Occupational contact dermatitis from acrylic monomer in paint. Contact Dermatitis 1999;40:228-9.

2. Kanerva L, Estlander T, Jolanki R, Alanko K. Occupational allergic contact dermatitis from 2,2-bis[4-(2-hydroxy-3-acryloxypropoxy) phenyl]-propane (epoxy diacrylate) in ultraviolet-cured inks. Contact Dermatitis 2000;43:56-9.

3. Kieć-Świerczyńska M, Kręcisz B, Świerczyńska-Machura D, Zaremba J. An epidemic of occupational contact dermatitis from acrylic glue. Contact Dermatitis 2005;52:121-5.

4. Björkner B, Dahlquist I, Fregert S. Allergic contact dermatitis from acrylates in ultraviolet curing inks. Contact Dermatitis 1980;6:405-9.

5. Nethercott JR, Jakubovic HR, Pilger C, Smith JW. Allergic contact dermatitis due to urethane acrylate in ultraviolet cured inks. Br J Ind Med 1983;40:241-50.

6. Whitfeld M, Frejman S. Allergic contact dermatitis to ultra violet cured inks. Austr J Dermatol 1991;32:65-8.

7. Goon ATJ, Rycroft RJG, McFadden JP. Allergic contact dermatitis from trimethylopropane triacrylate and pentaerythriol triacrylate. Contact Dermatitis 2002;7:249.

8. Estlander T, Jolanki R, Kanerva L. Occupational contact dermatitis from UV-cured lacquer containing dipropylene glycol diacrylate. Contact Dermatitis 1998;39:36. 